Original Research Paper

\title{
Products of Solid-Phase Probiotic Bacilli Fermentation Increase Food Conversion Efficiency and Stimulate Chicken Growth
}

\author{
${ }^{1}$ Mazanko Maria S., ${ }^{2}$ Aleksandr I. Klimenko, ${ }^{3}$ Ivan F. Gorlov, ${ }^{1}$ Alexander V. Usatov, ${ }^{3}$ Zoya B. Komarova, \\ ${ }^{3}$ Natalya I. Mosolova, ${ }^{3}$ Olga E. Krotova, ${ }^{3}$ Aleksandr N. Struk, ${ }^{1}$ Michael L. Chickindas and ${ }^{2}$ Maria A. Kolosova \\ ${ }^{1}$ Southern Federal University, Rostov-on-Don, Russia \\ ${ }^{2}$ Don State Agrarian University, Persianovsky, Russia \\ ${ }^{3}$ Povolzhsky Research Institute of Production and Processing of Meat and Dairy Industry, Volgograd, Russia
}

Article history

Received: 11-09-2018

Revised: 04-11-2018

Accepted: 03-12-2018

Corresponding Author:

Kolosova Maria A.,

Don State Agrarian University,

Persianovsky, Russia

Email: m.leonovaa@mail.ru

\begin{abstract}
Poultry farming is one of the major directions in agriculture. Agricultural poultry has high growth speed, productivity and is resistant to the industrial environment. Our group carried out a study of probiotic preparations of Bacillus subtilis KATMIRA1933 and Bacillus amyloliquefaciens B-1895 strains. These preparations were made by solid-phase fermentation and tested for dynamical germination of rearing flock (Highsex brown). The research was conducted at SD "Svetliy", structure department of PC "Agrofirm Vostok" (Volgograd region). Soybeans were used as the substrate for preparations. We investigated the influence of monocultural preparation and mixed bioadditives. The duration of the experiment was 120 days. It was shown that addition of the drugs to the poultry food leads to it's live weight gain (max $19 \%$ ) and decrease of food conversion factor ( $\min 1.98)$. The increase of erythrocyte $(\max 6 \%)$, leukocyte $(\max 2 \%)$ and hemoglobin $(\max 13 \%)$ content and the concentration protein fractions in poultry blood ( $\max 14 \%$ ) was also noted. Simultaneous use of two strains decreases their physiological effects. Bacterial components of preparations did not disturb the natural intestinal microbiota of the fowl. The abundance of Bifidobacterium and Lactobacillus strains was constant. Since preparations based on soybeans are cheap and straightforward to produce, using them can be highly efficient in modern poultry and livestock farming.
\end{abstract}

Keywords: Probiotics, Bacillus, Poultry Farming, Living Weight, Food Conversion

\section{Introduction}

Poultry farming is one of the major directions in agriculture. Domestic birds have a high rate of growth, productivity and resistance to industrial environment. Breeding and keeping poultry is less expensive compared to other livestock (Paul, 2009).

Bird meat is very rich in protein; also, it contains a complex of essential amino acids, lipids, vitamins and other biologically active substances. Production of poultry meat holds about $30 \%$ of the world meat industry, which is more than 100 million tons and this number continues to grow (Terry, 2008). About $90 \%$ of poultry farms are egg and broiler farms (Paul, 2009), therefore Gallus gallus is a dominant species used in the industry and this determines the relevance of investigations in its physiology.
To improve growth rates in chicken and disease prevention in many countries antibiotics, such as tetracycline, amoxicillin, penicillin, bacitracin, et cetera, are used (Diarra et al., 2014).

Usage of antibiotics in poultry farming leads to the emergence of antibiotic resistance and problems with bird microbiota (Diarra et al., 2014; Stanton, 2013).

An alternative to antibiotics is the usage of probiotics (Allen et al., 2013). Like antibiotics, probiotics inhibit the growth of bird gastric pathogens and decrease the occurrence of diseases. However, their use does not lead to the antibiotic resistance in gastric bacteria and accumulation of toxins in bird tissues (Angelakis, 2016; Blajman et al., 2015).

The general limitation for using probiotic drugs in poultry farming is their cost, which is higher than the cost of synthetic drugs (Ghadban, 2002). We suppose that the probiotic industry can be made cheaper by using
Science

Publications 
solid-phase bacterial cultivation, in which bacterial cells are grown on a substrate surface (like a biofilm). Such type of cultivation can increase bacterial probiotic activity (Aguilar et al., 2008; Ushakova et al., 2012) and increase their environmental stability and that allows us to make drying process cheaper and easier.

Earlier we showed that the usage of Bacillus amyloliquefaciens B-1895 (grown on the soybean surface, by the solid-phase method) increases broiler chicken growth speed and decreases food conversion factor (Chistyakov et al., 2015). Observations were carried out for 28 days. This article describes the results of more extended, 120-day experiments, with an expanded list of monitored parameters. Also, a preparation based on the Bacillus subtilis strain KATMIRA1933, whose probiotic properties were investigated by us in a series of previous studies was tested (Chistyakov et al., 2015; Prazdnova et al., 2015; AlGburi et al., 2016; Karlyshev et al., 2014).

\section{Materials and Methods}

The research was carried out according to the approved conditions at JV Svetly, which is a structural unit of CJSC Agrofirma "Vostok" (Volgograd region, Russia), the sow farm of the second order for poultry breeding of "Highsex brown".

\section{Probiotics}

Two strains of probiotic bacteria were used: B. subtilis KATMIRA1933, a fermented milk product isolate (Sutyak et al., 2008) and B. amyloliquefaciens B-1895, a soilderived microorganism.

The protocol for solid-phase fermentation of probiotic bacilli was described in detail in our study (Chistyakov et al., 2015). Briefly, bacterial strains were inoculated on plates with solid LB medium (Difco, MI) and incubated for 1 day at $37^{\circ} \mathrm{C}$. Soybeans $(1 \mathrm{~kg})$ were washed with running water, soaked for $12 \mathrm{~h}$ at room temperature, sterilized at $115^{\circ} \mathrm{C}$ for $40 \mathrm{~min}$, placed in an incubator and cooled down to $60^{\circ} \mathrm{C}$. The soybean preparation was inoculated with the biomass of bacteria from one plate, mixed thoroughly and incubated for $24 \mathrm{~h}$ at $42^{\circ} \mathrm{C}$ aerobically. The fermented substrate was milled with a meat grinder, distributed in a thin layer on metal trays and dried at $50^{\circ} \mathrm{C}$ to the humidity of $8-10 \%$. During this period the Bacillus sporulated. Viable cells were enumerated at each step of the process by plating to the appropriate solid medium.

\section{Staging the Experiment}

These preparations were introduced into the diet as additives. Additive No. 1 included a probiotic preparation based on the B. subtilis strain KATMIRA1933 (107-109 CFU viable spores per gram of the probiotic supplement) and extruded pumpkin press cake (also included to the main diet) as filler; additive no. 2 included a probiotic preparation based on $B$. amyloliquefaciens B-1895 (107-109 CFU viable spores per gram of the probiotic supplement) and extruded pumpkin press cake as filler; additive No. 3 included probiotic preparation based on B. subtilis KATMIRA1933 and B. amyloliquefaciens B-1895 (equal amounts, 107$109 \mathrm{CFU}$ viable spores per gram of the probiotic supplement) and extruded pumpkin press cake as filler. Doses of the preparations' administration were $1 \%$ in the overall structure of the poultry diet and the dose of probiotic supplements was $0.1 \%$. Each experimental bird was contained in a separate Big Dutchman (Germany) cell battery. The microclimate parameters were set according to the recommendations of "ISA Hendrix Genetics" (Holland). The birds were fed with standard mixed fodder manufactured at the feed mill of the company. Feeding of experimental birds was carried out according to NRC (1994). Weighing of experimental chickens was carried out weekly. The conversion of feed was calculated as the ratio between the weight of the expended feed and the weight gain of the bird.

\section{Bird State Monitoring}

\section{Weighing and Food Conversion}

All birds in each group were weighed individually at hatch, 1-10, 13, 14, 17 and 20 weeks of age. Feed Conversion Ratio (FCR) was described as the amount of feed needed (in $\mathrm{kg}$ ) to obtain one $\mathrm{kg}$ of weight increase of the poultry.

\section{Blood Parameters Monitoring}

Analysis of hematological and biochemical blood composition of experimental birds was performed strictly according to standard methods (Coles, 1986).

The Hemoglobin concentration was determined as described by Coles (1986). The plasma protein and albumin were determined by the Biuret method as described by Coles (1986) while globulin was calculated by subtracting the albumin from total plasma protein. Protein index was measured as the ratio between globulins and albumins. Serum urea and serum glucose were determined using a photoelectric colorimeter (GallenKamp and Son's, Ltd, England) as described by Coles (1986).

\section{Bird Microbiota Monitoring}

Analysis of excreted microbiota was performed monthly. About $10 \mathrm{~g}$ of excreta samples were mixed and homogenized. Homogenate of samples was then serially diluted from $10^{-1}$ to $10^{-7}$. Then $0.1 \mathrm{~mL}$ of dilutions $10^{-5}$ to $10^{-8}$ was spread on the appropriate agar media. The media used were: MRS agar for lactobacilli and yeasts, Bifido selective agar for bifidobacteria, Eosin methylene blue agar for $E$. coli and Salmonella-Shigella agar for Salmonella, Bile Esculin Azide Agar for Enterococcus, №10 media for Staphylococcus and nutrient agar for total aerobic bacteria. Selective agar plates used to enumerate Lactobacillus and Bifidobacterium species were incubated 
anaerobically for $48 \mathrm{~h}$ at $37^{\circ} \mathrm{C}$. Other plates were incubated aerobically for $24 \mathrm{~h}$ at $37^{\circ} \mathrm{C}$. The number of bacterial colonies was counted and results were expressed as $\log _{10}$ CFU per gram of fresh sample (Mookiah, 2014; Jeong, 2014). In all cases, the physiological norm was accounted according to recommendations of the industrial organization of "Highsex brown".

\section{Statistical Processing of Experimental Data}

The statistical significance of differences was determined by Student's t-test for independent samples at $\mathrm{p}<0.05$.

\section{Results}

\section{Monitoring of Bird Living Weight Dynamics}

The dynamics of the living weight of rearing birds and its comparison with the breed's standard (Hisex Brown Guide CS) is presented in Table 1. Starting from the 2nd week, the bird living weight of experimental groups tended to increase when compared to the control. At the age of 5 weeks, statistically significant difference in the living weight of hens from I and II of the test groups was found in comparison with the control, which survived up to 10 weeks. Living weight of hens in experimental groups at the age of 10 weeks exceeded the control by 4.24 $(\mathrm{P}<0.001), 3.84(\mathrm{P}<0.001)$ and $3.00 \%(\mathrm{P}<0.01)$; males - by $3.96(\mathrm{P}<0.01), \quad 3.66 \quad(\mathrm{P}<0.01)$ and $2.93 \% \quad(\mathrm{P}<0.05)$, respectively.

Starting from the 2nd week the living weight of birds, the experimental groups tended to increase with respect to control. At the age of 5 weeks, a statistically significant difference in the living weight of chicks from the test groups I and II was found in comparison to the control and the difference remained until 10-week age.

At the age of 13 weeks, the living weight of both hens and roosters also exceeded control: the hens of the 1 st test group were heavier by $141.7 \mathrm{~g}$ (14.44\%, $\mathrm{P}<0.001)$, in the second experimental group by $99.7 \mathrm{~g}$ $(10.16 \% ; \mathrm{P}<0.001)$ and by $40.7 \mathrm{~g}(4.15 \%, \mathrm{P}<0.001)$ in the third experimental group; Roosters of the first group were heavier by $339.0 \mathrm{~g}(27.45 \%, \mathrm{P}<0.001)$, in group II by $23.40 \mathrm{~g}(18.94 \%, \mathrm{P}<0.001)$ and in the third experimental group- by $191.0 \mathrm{~g}(15.55 \%$; $\mathrm{P}<0.001)$. By the age of 20 weeks, the difference in living weight between the test groups and the control group had reduced, as the indicator reaches the age plateau.

Table 1: Experimental birds living weight dynamics

\begin{tabular}{|c|c|c|c|c|c|c|c|c|c|c|}
\hline \multirow{2}{*}{\multicolumn{2}{|c|}{ Age, weeks }} & \multirow{3}{*}{$\begin{array}{l}\text { St, } \\
\text { breed } \\
3\end{array}$} & \multicolumn{8}{|l|}{ Group } \\
\hline & & & \multirow{2}{*}{$\begin{array}{l}\text { control } \\
4\end{array}$} & \multirow{2}{*}{$\begin{array}{l}\text { Variation } \\
\text { St, \% } \\
5\end{array}$} & \multirow{2}{*}{$\begin{array}{l}\text { I } \\
\text { experimental } \\
6\end{array}$} & \multirow{2}{*}{$\begin{array}{l}\text { Variation } \\
\text { St, \% } \\
7\end{array}$} & \multirow{2}{*}{$\begin{array}{l}\text { II } \\
\text { experimental } \\
8\end{array}$} & \multirow{2}{*}{$\begin{array}{l}\text { Variation } \\
\text { St, \% } \\
9\end{array}$} & \multirow{2}{*}{$\begin{array}{l}\text { III } \\
\text { experimental } \\
10\end{array}$} & \multirow{2}{*}{$\begin{array}{l}\text { Variation } \\
\text { St, \% } \\
11\end{array}$} \\
\hline 1 & 2 & & & & & & & & & \\
\hline \multirow[t]{2}{*}{ Days } & hens & 40 & $36,7+0,01$ & $-8,9$ & $36,7+0,01$ & $-8,9$ & $36,8+0,01$ & $-8,7$ & $36,7+0,01$ & $-8,9$ \\
\hline & males & 40 & $37,0+0,01$ & $-8,1$ & $37,0+0,01$ & $-8,1$ & $37,1+0,01$ & $-7,8$ & $37,0+0,01$ & $-8,1$ \\
\hline \multirow[t]{2}{*}{1} & hens & 65 & $57,2+0,39$ & $-13,4$ & $57,9+0,41$ & $-12,3$ & $58,3+0,27$ & $-11,5$ & $57,5+0,31$ & $-13,0$ \\
\hline & males & 70 & $58,3+0,94$ & $-20,1$ & $58,8+0,89$ & $-19,0$ & $58,7+0,77$ & $-19,3$ & $58,6+0,85$ & $-19,5$ \\
\hline \multirow[t]{2}{*}{2} & hens & 125 & $95,2+1,05$ & $-31,3$ & $98,4+1,16$ & $-27,0$ & $96,7+1,24$ & $-29,3$ & $97,8+1,03$ & $-27,8$ \\
\hline & males & 140 & $96,7+1,07$ & $-44,8$ & $100,0+1,45$ & $-40,0$ & $100,1+1,19$ & $-39,9$ & $98,4+1,09$ & $-42,3$ \\
\hline \multirow[t]{2}{*}{3} & hens & 180 & $145,9+1,63$ & $-23,4$ & $148,8+1,59$ & $-20,9$ & $146,8+1,21$ & $-22,6$ & $146,8+1,27$ & $-22,6$ \\
\hline & males & 270 & $156,1+1,86$ & $-72,9$ & $161,6+2,13$ & $-67,1$ & $159,4+1,43$ & $-69,4$ & $158,0+1,39$ & $-70,9$ \\
\hline \multirow[t]{2}{*}{4} & hens & 250 & $208,7+2,18$ & $-19,7$ & $214,9+2,91$ & $-16,3$ & $210,0+3,14$ & $-19,0$ & $210,7+2,73$ & $-18,7$ \\
\hline & males & 330 & $254,4+2,49$ & $-29,7$ & $260,4+3,07$ & $-26,7$ & $257,3+3,65$ & $-28,3$ & $255,4+4,08$ & $-29,2$ \\
\hline \multirow[t]{2}{*}{5} & hens & 330 & $284,6+2,97$ & $-15,9$ & $295,3+3,40 *$ & $-11,9$ & $293,3+3,21 *$ & $-12,5$ & $288,6+3,14$ & $-14,3$ \\
\hline & males & 440 & $361,4+2,89$ & $-21,7$ & $373,4+3,41 *$ & $-17,8$ & $371,1+2,74^{*}$ & $-18,6$ & $368,6+2,92$ & $-19,4$ \\
\hline \multirow[t]{2}{*}{6} & hens & 420 & $412,3+4,29$ & $-1,9$ & $434,1+5,12 * *$ & $+3,4$ & $433,2+5,51 * *$ & $+3,1$ & $429,4+5,32 *$ & $+2,2$ \\
\hline & males & 560 & $478,3+5,23$ & $-17,1$ & $498,0+6,17 *$ & $-12,5$ & $495,9+4,96^{*}$ & $-12,9$ & $492,3+5,09$ & $-13,8$ \\
\hline \multirow[t]{2}{*}{7} & hens & 520 & $509,8+4,81$ & $-2,0$ & $526,0+6,12 *$ & $+1,2$ & $525,1+5,38 *$ & $+1,0$ & $519,2+5,71$ & $-0,2$ \\
\hline & males & 660 & $619,0+3,79$ & $-6,6$ & $652,9+4,67 * *$ & $-1,1$ & $649,8+5,21 * *$ & $-1,6$ & $639,1+5,51 *$ & $-3,3$ \\
\hline \multirow[t]{2}{*}{8} & hens & 600 & $628,9+6,17$ & $+4,82$ & $654,2+7,23 * *$ & $+9,0$ & $648,5+7,49 *$ & $+8,1$ & $643,7+6,97$ & $+7,3$ \\
\hline & males & 730 & $782,2+3,62$ & $+7,15$ & $798,8+4,45^{*}$ & $+9,4$ & $794,6+4,01 *$ & $+8,9$ & $789,6+4,71$ & $+8,2$ \\
\hline \multirow[t]{2}{*}{9} & hens & 730 & $727,4+4,69$ & $-0,35$ & $761,7+5,18 * * *$ & $+4,3$ & $757,6+6,04 * * *$ & $+3,8$ & $754,2+8,12 * *$ & $+3,3$ \\
\hline & males & 910 & $983,5+3,17$ & $+8,0$ & $1010,2+2,94 * * *$ & $+11,8$ & $1008,4+4,11 * *$ & $+10,8$ & $997,7+4,79 *$ & $+9,6$ \\
\hline \multirow[t]{2}{*}{10} & hens & 850 & $867,9+4,15$ & $+2,2$ & $904,7+5,01 * * *$ & $+6,4$ & $901,2+5,84 * * *$ & $+6,0$ & $894,0+7,13 * *$ & $+5,2$ \\
\hline & males & 1020 & $1195,8+5,49$ & $+17,2$ & $1243,1+6,93 * *$ & $+21,9$ & $1239,6+6,17 * *$ & $+21,5$ & $1230,8+8,43^{*}$ & $+20,7$ \\
\hline \multirow[t]{2}{*}{13} & hens & 1020 & $981,3+8,18$ & $-3,9$ & $1123,0+9,86^{* * *}$ & $+10,1$ & $1081,0+8,91 * * *$ & $+5,9$ & $1022,0+10,03 * *$ & $+0,2$ \\
\hline & males & 1350 & $1235,0+10,71$ & $-9,3$ & $1574,0+14,69 * * *$ & $+16,6$ & $1469,0+15,12 * * *$ & $+8,8$ & $1426,0+13,44 * * *$ & $*+5,6$ \\
\hline \multirow[t]{2}{*}{14} & hens & 1150 & $1139,0+8,84$ & $-0,9$ & $1207,0+9,69 * * *$ & $+4,9$ & $1194,0+15,15^{* *}$ & $+3,8$ & $1162,0+7,17^{*}$ & $+1,8$ \\
\hline & males & 1450 & $1555,0+12,57$ & $+7,2$ & $1695,0+14,03 * * *$ & $+16,9$ & $1629,0+16,64 * * *$ & $+12,3$ & $1587,0+15,94 *$ & $+9,5$ \\
\hline \multirow[t]{2}{*}{17} & hens & 1400 & $1488,0+9,63$ & $+6,3$ & $1612,0+11,46 * * *$ & $+15,1$ & $1573,0+17,13 * *$ & $+12,4$ & $1508,0+4,73^{*}$ & $+7,7$ \\
\hline & males & 1800 & $2008,0+8,84$ & $+11,6$ & $2125,0+16,15 * * *$ & $+18,1$ & $2088,0+11,59 * *$ & $+16,0$ & $2061,0+10,87 *$ & $+14,5$ \\
\hline \multirow[t]{2}{*}{20} & hens & 1700 & $1721,0+11,19$ & $+1,2$ & $1808,0+13,97 * * *$ & $+6,4$ & $1789,0+12,67 * * *$ & $+5,2$ & $1761,0+13,24 *$ & $+3,6$ \\
\hline & males & 2050 & $2429,0+11,73$ & $+18,5$ & $2497,0+15,44 *$ & $+21,8$ & $2485,0+14,81^{*}$ & $+21,2$ & $2468,0+11,46^{*}$ & $+20,4$ \\
\hline
\end{tabular}

$*-\mathrm{P}<0,05 ; * *-\mathrm{P}<0,01 ; * * *-\mathrm{P}<0,001$, data is presented at means and standard error 
In our experience, the birds of all experimental groups gained normative living weight at the beginning of oviposition. However, both females and males exceeded the living weight of the birds in the control group: in hens of the experimental group I -by 5.06, in experimental group II by 3.95 and in experimental group III - by $2.32 \%$; males of the experimental group I - by 2.80 , in group II by 2.31 in test group II by $1.61 \%$.

Comparing the experimental groups with each other, it should be noted that a higher living weight had been observed in experimental group I. The parameters of the living weight of the second experimental group were slightly inferior to the first experimental group. Throughout the growing period, the living weight of both females and males of the third test group was inferior to the birds from the control groups, groups I and II and only at the 9-week-old age reached significant difference compared to the control group.

The food conversion rate (Chistyakov et al., 2015) was 2.9 for hens in control group, 2.79 for the test group I and 2.8 for the test group II and 2.82 for the test group III. For males in the control, the conversion rate was $2.05,1.98$ in the test group I, 1.98 in the test group II and 1.99 in the test group III. In all cases, the conversion rate for the experimental groups was significantly different from the control group $(\mathrm{P}<0.05)$.

According to the recommendations of the producers of egg cross-breeds, the deviations in living weight of \pm $15 \%$ (Hisex Brown Guide CS) are allowed. Deviations from the standard of hens at the age of 20 weeks. did not exceed the norm. Deviations in living weight of males at artificial insemination are allowed up to $\pm 20 \%$ (Hisex Brown Guide CS).
Deviations from the standard in males did not exceed the norm as well. Similar deviations in the live mass did not lead to the appearance of significant changes in the productivity of the layers and the quality of sperm of the males (data is not shown).

Beginning from week 7 , the indices of homogeneity of the herd of both males and females exceeded $90 \%$, starting from week $17-97 \%$. A herd is considered homogeneous if the ratio is at $90 \%$ or higher (Hisex Brown Guide CS).

The output of juvenile chicken at the age of 16-17 weeks was $100 \%$, i.e. All birds remained in the group reached (according to the results of boning) the adult state. The survivability of birds in the experimental groups was $100 \%$, in the control group and the death of one head was recorded, i.e. survivability was $98.57 \%$. In males, the birds' survival was $100 \%$ in all groups.

\section{Monitoring of Bird Blood Cellular and Biochemical Composition}

Hematological and biochemical blood composition of the test birds was analyzed, the results of the analysis are presented in Table 2 and 3.

The obtained data of the hematological composition of the blood of rearing birds from the experimental groups indicate that all the studied parameters corresponded to the physiological norm (Hisex Brown Guide CS). The level of erythrocytes, leukocytes and hemoglobin in the blood changed in both age and intergroup aspects (Table 2).

At the age of 3 days (when completing the experimental groups) all the studied parameters were approximately at the same level and within the physiological norm.

Table 2: Blood element quantity of rearing birds

\begin{tabular}{|c|c|c|c|c|c|}
\hline \multirow[b]{2}{*}{ Parameter } & & \multicolumn{4}{|l|}{ Group } \\
\hline & & control & I experimental & II experimental & III experimental \\
\hline \multirow{3}{*}{$\begin{array}{l}3 \text { Weeks } \\
\mathrm{RBC}, 10^{12} / л\end{array}$} & & & & & \\
\hline & Hens & $2,67+0,04$ & $2,66+0,03$ & $2,67+0,04$ & $2,67+0,04$ \\
\hline & Males & $2,54+0,03$ & $2,56+0,04$ & $2,55+0,03$ & $2,54+0,03$ \\
\hline \multirow[t]{2}{*}{$\mathrm{WBC}, 10^{9} / л$} & Hens & $26,94+0,51$ & $27,01+0,64$ & $26,98+0,49$ & $27,04+0,59$ \\
\hline & Males & $26,69+0,44$ & $26,75+0,52$ & $26,76+0,63$ & $26,78+0,67$ \\
\hline \multirow[t]{2}{*}{$\mathrm{Hb}, \mathrm{g} / \mathrm{l}$} & Hens & $99,41+2,73$ & $99,64+2,84$ & $99,59+2,37$ & $99,49+3,11$ \\
\hline \multirow{2}{*}{\multicolumn{6}{|c|}{4 weeks }} \\
\hline & & & & & \\
\hline \multirow[t]{2}{*}{$\mathrm{RBC}, 10^{12} / л$} & Hens & $2,88+0,05$ & $2,99+0,06$ & $2,95+0,07$ & $2,96+0,06$ \\
\hline & Males & $2,69+0,04$ & $2,78+0,07$ & $2,71+0,06$ & $2,70+0,05$ \\
\hline \multirow[t]{2}{*}{ WBC, $10^{9} / л$} & Hens & $27,36+0,49$ & $27,91+0,48$ & $27,86+0,74$ & $27,85+0,64$ \\
\hline & Males & $26,92+0,31$ & $27,23+0,94$ & $27,19+0,51$ & $27,11+0,59$ \\
\hline \multirow[t]{2}{*}{$\mathrm{Hb}, \mathrm{g} / \mathrm{l}$} & Hens & $109,84+2,03$ & $121,17+1,49 *$ & $120,93+1,52 *$ & $120,89+1,31 *$ \\
\hline & Males & $101,15+1,74$ & $107,14+2,43$ & $107,09+2,49$ & $106,33+2,19$ \\
\hline \multirow{3}{*}{$\begin{array}{l}9 \text { weeks } \\
\mathrm{RBC}, 10^{12} / л\end{array}$} & & & & & \\
\hline & Hens & $2,98+0,05$ & $3,16+0,04$ & $3,11+0,06$ & $3,08+0,08$ \\
\hline & Males & $2,83+0,04$ & $3,08+0,05$ & $3,07+0,04$ & $3,06+0,04$ \\
\hline \multirow[t]{2}{*}{$\mathrm{WBC}, 10^{9} /$ л } & Hens & $27,78+0,54$ & $28,43+0,71$ & $28,39+0,55$ & $28,41+0,37$ \\
\hline & Males & $27,18+0,46$ & $27,91+0,84$ & $27,88+0,49$ & $27,69+0,29$ \\
\hline \multirow[t]{2}{*}{$\mathrm{Hb}, \mathrm{g} / \mathrm{l}$} & Hens & $118,44+1,71$ & $133,84+2,19^{*}$ & $133,12+2,01 *$ & $131,18+1,91^{*}$ \\
\hline & Males & $109,57+1,24$ & $119,46+1,63^{*}$ & $118,87+1,13 *$ & $118,71+1,56$ \\
\hline
\end{tabular}

*- $\mathrm{P}<0,05 ; * *-\mathrm{P}<0,01 ; * * *-\mathrm{P}<0,001$, data is presented at means and standard error 
At 4-week age, there was a stable tendency towards the increase in the content of erythrocytes and leukocytes in the birds of the experimental groups (pullets, cockerels). Experimental group hens had a significant increase in hemoglobin in the blood compared to the control of $10.36(\mathrm{P}<0.05), 10.09(\mathrm{P}<0.05)$ and $10.06 \%$ $(\mathrm{P}<0.05)$, respectively.

At the age of 9 weeks, an increase in the content of red blood cells and leukocytes in the blood of rearing birds of experimental groups in relation to the control was also observed. The content of hemoglobin in the blood, in both females and males, increased significantly: in the hens of the 1st experimental group by $13.02(\mathrm{P}<0.05)$, in the group II - by $12.39(\mathrm{P}<0.05)$ and in group III - by $10,76 \%$
$(\mathrm{P}<0.05)$ compared with the control; in the males the increase was $9.02(\mathrm{P}<0.05), 8.49(\mathrm{P}<0.05)$ and $8.34 \%$ $(\mathrm{P}<0.05)$, respectively.

It should be noted that in the males of experimental groups all the studied parameters were slightly lower than in the females.

The biochemical serum composition of rearing birds of the experimental groups was also within the physiological norm. At the age of 3 days, all the parameters studied in the birds of experimental groups were at the same level. The use of the studied additives in the rations of both females and males in experimental groups had a positive effect on the protein content and its fractions as early as at 4-week age (Table 3 ).

Table 3: Biochemical parameters of rearing birds serum

\begin{tabular}{|c|c|c|c|c|c|}
\hline \multirow[b]{2}{*}{$\begin{array}{l}\text { Parameter } \\
1\end{array}$} & \multirow[b]{2}{*}{2} & \multicolumn{4}{|l|}{ Group } \\
\hline & & $\begin{array}{l}\text { control } \\
3\end{array}$ & $\begin{array}{l}\text { I experimental } \\
4\end{array}$ & $\begin{array}{l}\text { II experimental } \\
5\end{array}$ & $\begin{array}{l}\text { III experimental } \\
6\end{array}$ \\
\hline \multicolumn{6}{|l|}{3 days } \\
\hline \multirow[t]{2}{*}{$\mathrm{TP}, \mathrm{g} / 1$} & hens & $48,10+0,53$ & $48,12+0,80$ & $48,10+0,73$ & $48,11+0,78$ \\
\hline & males & $48,84+0,61$ & $48,81+0,59$ & $48,85+0,67$ & $48,84+0,77$ \\
\hline \multirow[t]{2}{*}{ Albumines, g/l } & hens & $16,35+0,16$ & $16,38+0,21$ & $16,36+0,18$ & $16,37+0,14$ \\
\hline & males & $16,64+0,25$ & $16,65+0,72$ & $16,65+0,44$ & $16,64+0,39$ \\
\hline \multirow[t]{2}{*}{ Globulines, g/l } & hens & $31,75+0,40$ & $31,74+0,22$ & $31,74+0,52$ & $31,74+0,61$ \\
\hline & males & $32,20+0,29$ & $32,16+0,41$ & $32,20+0,69$ & $32,20+0,74$ \\
\hline \multirow[t]{2}{*}{ Protein index } & hens & 0,51 & 0,52 & 0,52 & 0,52 \\
\hline & males & 0,52 & 0,52 & 0,52 & 0,52 \\
\hline \multirow[t]{2}{*}{ UREA, mmol/1 } & hens & $2,35+0,09$ & $2,35+0,08$ & $2,36+0,07$ & $2,35+0,11$ \\
\hline & males & $2,33+0,08$ & $2,34+0,13$ & $2,33+0,11$ & $2,33+0,09$ \\
\hline \multirow[t]{2}{*}{ Glucose, mmol/1 } & hens & $4,67+0,07$ & $4,69+0,09$ & $4,67+0,08$ & $4,68+0,08$ \\
\hline & males & $4,68+0,09$ & $4,68+0,07$ & $4,69+0,05$ & $4,68+0,09$ \\
\hline \multicolumn{6}{|l|}{4 weeks } \\
\hline \multirow[t]{2}{*}{$\mathrm{TP}, \mathrm{g} / 1$} & hens & $51,77+2,55$ & $54,84+2,61$ & $54,69+3,71$ & $54,03+2,37$ \\
\hline & males & $52,49+2,45$ & $55,12+1,59$ & $55,09+2,81$ & $54,92+1,64$ \\
\hline \multirow[t]{2}{*}{ Albumines, g/l } & hens & $20,96+1,27$ & $22,51+1,18$ & $22,39+1,11$ & $22,07+1,14$ \\
\hline & males & $21,39+1,96$ & $23,15+1,43$ & $23,18+1,69$ & $22,96+1,71$ \\
\hline \multirow[t]{2}{*}{ Globulines, g/l } & hens & $30,81+1,23$ & $32,33+1,37$ & $32,30+1,61$ & $31,96+1,18$ \\
\hline & males & $31,10+1,46$ & $31,97+1,32$ & $31,91+1,54$ & $31,96+1,19$ \\
\hline \multirow[t]{2}{*}{ Protein index } & hens & 0,68 & 0,69 & 0,69 & 0,69 \\
\hline & males & 0,69 & 0,72 & 0,73 & 0,72 \\
\hline \multirow[t]{2}{*}{ UREA, mmol/l } & hens & $3,12+0,05$ & $3,43+0,07$ & $3,41+0,09$ & $3,39+0,06$ \\
\hline & males & $3,39+0,07$ & $3,56+0,09$ & $3,55+0,08$ & $3,55+0,11$ \\
\hline \multirow[t]{2}{*}{ Glucose, mmol/1 } & hens & $7,25+0,09$ & $7,94+0,07 * *$ & $7,89+0,08^{* *}$ & $7,87+0,09 * *$ \\
\hline & males & $6,91+0,11$ & $7,88+0,09 * *$ & $7,80+0,12 *$ & $7,80+0,11^{*}$ \\
\hline \multicolumn{6}{|l|}{9 weeks } \\
\hline \multirow[t]{2}{*}{$\mathrm{TP}, \mathrm{g} / 1$} & hens & $52,61+0,41$ & $55,83+0,39 *$ & $55,79+0,48^{*}$ & $55,75+0,37 *$ \\
\hline & males & $53,78+0,38$ & $57,19+0,44 *$ & $57,01+0,35 *$ & $56,99+0,48 *$ \\
\hline \multirow[t]{2}{*}{ Albumines, g/l } & hens & $21,15+0,14$ & $23,35+0,15 * *$ & $23,32+0,11 * *$ & $23,31+0,12 * *$ \\
\hline & males & $22,09+0,12$ & $25,12+0,17 * *$ & $24,98+0,09 * *$ & $24,72+0,14^{*}$ \\
\hline \multirow[t]{2}{*}{ Globulines, g/l } & hens & $31,46+1,09$ & $32,48+1,11$ & $32,47+1,17$ & $32,44+1,13$ \\
\hline & males & $31,69+1,21$ & $32,07+1,33$ & $32,03+1,18$ & $32,27+1,64$ \\
\hline \multirow[t]{2}{*}{ Protein index } & hens & 0,67 & 0,72 & 0,72 & 0,72 \\
\hline & males & 0,70 & 0,78 & 0,78 & 0,77 \\
\hline \multirow[t]{2}{*}{ UREA, mmol/1 } & hens & $3,24+0,09$ & $3,85+0,07 *$ & $3,84+0,05^{*}$ & $3,74+0,04^{*}$ \\
\hline & males & $3,32+0,06$ & $3,96+0,05 *$ & $3,94+0,08 *$ & $3,92+0,09 *$ \\
\hline \multirow[t]{2}{*}{ Glucose, mmol/1 } & hens & $7,59+0,08$ & $8,42+0,07^{*}$ & $8,40+0,07 *$ & $8,34+0,09^{*}$ \\
\hline & males & $7,55+0,09$ & $8,46+0,08^{*}$ & $8,38+0,05^{*}$ & $8,36+0,08^{*}$ \\
\hline
\end{tabular}

$*-\mathrm{P}<0,05 ; * *-\mathrm{P}<0,01 ; * * *-\mathrm{P}<0,001$, data is presented at means and standard error 
A distinct tendency of increase in total serum protein was observed in the experimental groups: in hens of the first experimental group by 5.93 ; 2nd by 5.64 ; and 3 rd by $4.37 \%$; in roosters by $5.01 ; 4.95$ and $4.63 \%$ related to the control. A similar situation was observed in the level of albumin in the serum of both hens and roosters. The content of urea was also slightly higher in birds of the experimental groups.

The content of glucose in the blood serum significantly increased in comparison to the control: in the first group of hens by $9.52(\mathrm{P}<0.01)$, in the second by $8.83(\mathrm{P}<0.01)$ and in the third - by $8.55 \%(\mathrm{P}<0.01)$; in roosters the numbers were $14.00 \quad(\mathrm{P}<0.01), 12.88$ $(\mathrm{P}<0.05)$ and $12.88 \%(\mathrm{P}<0.05)$ respectively.

At 9 weeks of age, both males and females of the experimental groups showed a significant difference in the content of the total protein in the blood serum compared to the control: in the experimental group I, the hens had $6.12(\mathrm{P}<0.05)$, in group II - $6.04(\mathrm{P}<0.05)$, in group III - 5.97\% $(\mathrm{P}<0.05)$; more total protein. In males, the level of serum total protein was increased by 6.34 $(\mathrm{P}<0.05), \quad 6.01 \quad(\mathrm{P}<0.05) \quad$ and $\quad 5.96 \% \quad(\mathrm{P}<0.05)$, respectively. The level of serum albumin in the test group hens exceeded the control by $10.40(\mathrm{P}<0.01)$,
$10.26(\mathrm{P}<0.01)$ and $10.22 \%(\mathrm{P}<0.05)$; for cockerels these numbers were $13.72(\mathrm{P}<0.01), 13.08 \quad(\mathrm{P}<0.01)$ and $11.91 \%(\mathrm{P}<0.01)$.

The data cited above may indirectly indicate a positive effect of probiotics on the metabolic rate in the body of test birds. Biochemical tests, designed to confirm or disprove this assumption, will be the subject of further research.

Thus, the maximum values of biochemical parameters of the blood were recorded in the first test group, in which the supplement 1 was tested.

\section{Microbiota Monitoring}

Results of the monthly excreta analysis are provided in Table 4.

The number of bifidobacteria in all samples at all stages of the selection exceeded $10^{6} \mathrm{CFU} / \mathrm{g}$. Salmonella and Shigella bacteria were not detected in any sample during the entire study.

The number of bacteria belonging to $g$. Lactobacillus in the control did not change and was $1.0 \pm 0.2-1.2 \pm 0.1 \cdot 10^{7} \mathrm{CFU} / \mathrm{g}$, in the experimental groups the number of lactobacilli increased slightly with time and reached $2.3 \pm 0.4-2.5 \pm 0.3 \cdot 10^{7} \mathrm{CFU} / \mathrm{g}$.

Table 4: Microbiology of a bird excreta

\begin{tabular}{|c|c|c|c|c|}
\hline \multirow[b]{2}{*}{ Probe selection date } & \multicolumn{4}{|l|}{ Group } \\
\hline & control & I experimental & II experimental & III experimental \\
\hline \multicolumn{5}{|c|}{ Lactobacillus, $10^{7} \mathrm{CFU} / \mathrm{g}$} \\
\hline 11.09 .16 & $1,0 \pm 0,2$ & $1,3 \pm 0,2$ & $0,6 \pm 0,3$ & $0,7 \pm 0,4$ \\
\hline 11.10 .16 & $1,0 \pm 0,3$ & $0,6 \pm 0,2$ & $0,5 \pm 0,3$ & $0,7 \pm 0,2$ \\
\hline 11.11 .16 & $1,2 \pm 0,4$ & $1,4 \pm 0,3$ & $1,3 \pm 0,4$ & $1,4 \pm 0,3$ \\
\hline 26.11 .16 & $1,2 \pm 0,1$ & $2,3 \pm 0,4$ & $2,5 \pm 0,3$ & $2,5 \pm 0,4$ \\
\hline \multicolumn{5}{|c|}{ E. coli and coliforms, $10^{7} \mathrm{CFU} / \mathrm{g}$} \\
\hline 11.09 .16 & $6,1 \pm 0,8$ & $9,2 \pm 0,8$ & $8,1 \pm 1,1$ & $5,8 \pm 0,8$ \\
\hline 11.10 .16 & $2,7 \pm 0,3$ & $2,1 \pm 0,5$ & $2,3 \pm 0,5$ & $1,8 \pm 0,3$ \\
\hline 11.11 .16 & $4,5 \pm 0,6$ & $2,0 \pm 0,6$ & $1,5 \pm 0,4$ & $1,0 \pm 0,1$ \\
\hline 26.11 .16 & $8,3 \pm 1,1$ & $5,6 \pm 0,6$ & $5,6 \pm 0,8$ & $7,8 \pm 1,2$ \\
\hline \multicolumn{5}{|c|}{ Enterococcus, $10^{6} \mathrm{CFU} / \mathrm{g}$} \\
\hline 11.09 .16 & $6,3 \pm 0,9$ & $8,6 \pm 0,9$ & $2,1 \pm 0,3$ & $1,9 \pm 0,3$ \\
\hline 11.10 .16 & $3,2 \pm 0,7$ & $5,7 \pm 0,8$ & $5,5 \pm 1,2$ & $0,8 \pm 0,3$ \\
\hline 11.11 .16 & $5,3 \pm 1,2$ & $0,7 \pm 0,3$ & $1,2 \pm 0,4$ & $1,4 \pm 0,3$ \\
\hline 26.11 .16 & $1,7 \pm 0,3$ & $2,0 \pm 0,5$ & $1,4 \pm 0,4$ & $1,9 \pm 0,5$ \\
\hline \multicolumn{5}{|c|}{ Stapylococcus, $10^{6} \mathrm{CFU} / \mathrm{g}$} \\
\hline 11.09 .16 & $5,8 \pm 0,8$ & $3,8 \pm 1,0$ & $1,3 \pm 0,6$ & $1,8 \pm 0,3$ \\
\hline 11.10 .16 & $3,9 \pm 0,6$ & $3,9 \pm 0,8$ & $5,2 \pm 1,2$ & $4,8 \pm 0,7$ \\
\hline 11.11 .16 & $2,9 \pm 0,6$ & $2,2 \pm 0,3$ & $2,0 \pm 0,6$ & $2,3 \pm 0,6$ \\
\hline 26.11 .16 & $3,6 \pm 1,0$ & $1,3 \pm 0,4$ & $1,1 \pm 0,2$ & $1,8 \pm 0,5$ \\
\hline \multicolumn{5}{|l|}{ Candida, $10^{4} \mathrm{CFU} / \mathrm{g}$} \\
\hline 11.09 .16 & $1,0 \pm 0,3$ & $5,1 \pm 1,2$ & $3,6 \pm 0,6$ & $2,8 \pm 0,5$ \\
\hline 11.10 .16 & $10,1 \pm 1,2$ & $5,7 \pm 0,9$ & $5,0 \pm 1,2$ & $6,8 \pm 0,9$ \\
\hline 11.11 .16 & $11,2 \pm 1,4$ & $6,0 \pm 1,0$ & $8,0 \pm 1,2$ & $8,1 \pm 1,0$ \\
\hline 26.11 .16 & $0,3 \pm 0,1$ & $2,3 \pm 0,5$ & $3,0 \pm 0,7$ & $6,1 \pm 0,9$ \\
\hline \multicolumn{5}{|c|}{ B. amyloliquefaciens $B-1895,10^{3} \mathrm{CFU} / \mathrm{g}$} \\
\hline 11.09 .16 & - & - & - & - \\
\hline 11.10 .16 & - & - & - & - \\
\hline 11.11 .16 & - & - & $2,0 \pm 0,5$ & - \\
\hline 26.11 .16 & - & - & $1,5 \pm 0,5$ & $2,0 \pm 0,5$ \\
\hline
\end{tabular}


In the paper by Jeong and Kim (2014), there is also a slight increase in the number of lactobacilli when $B$. subtilis is added to the feed. This can indicate the symbiotic interaction of probiotic bacilli with the microbiota of the gastrointestinal tract of birds.

The number of coliform bacteria fluctuated over a wide range $\left(1.0 \pm 0.1-9.2 \pm 0.8 \cdot 10^{7} \mathrm{CFU} / \mathrm{g}\right)$. In the results of October 11 and subsequent, there was a decrease in the number of coliform bacteria in the groups receiving all types of probiotic drugs, in comparison to the control group.

The number of Stapylococcus bacteria was $1.1 \pm 0.2-$ $5.8 \pm 0.8 \cdot 10^{6} \mathrm{CFU} / \mathrm{g}$. One can note a tendency of the number of staphylococci in the litter to decrease with time in all the groups studied. The number of staphylococci in the control group was higher than in the experimental group, in all cases, except for the sample from October 11.

The number of enterococci fluctuated within $0,7 \pm$ $0,3-8,6 \pm 0,9 \cdot 10^{6} \mathrm{CFU} / \mathrm{g}$, as a whole there is a tendency to decrease the number of enterococci in the excreta of all groups.

Among other things, the presence of Candida spp was observed, which varied considerably in the range 0.3 $\pm 0.1-11.2 \pm 1.4 \cdot 10^{4} \mathrm{CFU} / \mathrm{g}$.

Initially, bacilli were not found in chicken excrements. However, after two months $B$. amyloliquefaciens $B-1895$ bacteria appeared in the amount of $1.5 \pm 0.5-2 \pm 0.5 \cdot 10^{3} \mathrm{CFU} / \mathrm{g}$ in chicken treated with $B$. amyloliquefaciens $B-1895$ or the mixed preparation.

During the monitoring, there was no decrease in the quantitative and percentage share of lacto- and bifidobacteria. Introduced preparations did not lead to a violation of the microflora of hens, did not inhibit the growth of useful probiotic bacteria. There was a tendency of the abundance of enterococci and staphylococci, coliform bacteria to decrease.

\section{Discussion}

As was shown above, the introduction of probiotic bacteria into the diet of birds led to a live weight increase, an improvement of hematological and biochemical blood composition.

The living weight of the experimental groups birds tended to increase with respect to control.

A similar effect of the growth parameters increase and birds weight gain by improving the efficiency of feed conversion with introduction of probiotics into the food has been described in a number of works (Chistyakov et al., 2015; Li et al., 2014; Timmerman et al., 2006; Liu et al., 2012; Mountzouris et al., 2007).

However, most of the results described in the current scientific literature on the stimulation of chicken growth were obtained in broiler chickens that are genetically predisposed to accelerated mass gain. The object of our study was Highsex brown cross, the selection of which is oriented to the parameters of egg production. Nevertheless, with the action of probiotic bacilli on this cross, the effects of stimulating mass gain and improving feed conversion similar to those for broilers were obtained. Apparently, the reaction to the stimulating effect of bacilli is not associated with broiler-specific gene complexes and is a specific feature of Gallus gallus.

In all cases, the conversion rate for the experimental groups was significantly different from the control group $(\mathrm{P}<0.05)$. Bacilli are known to produce a large number of lytic enzymes (Liu et al., 2013). The observed effects are present since proteases, amylases and cellulases of bacilli contribute to better digestion of food.

The content of erythrocytes, leukocytes, hemoglobin in the blood, in both females and males test birds increased.

Differences in blood composition were not observed in all the cases of probiotic use in birds. When feeding birds with bacteria of genus Lactobacillus, Bifidobacterium, Pediococcus, there were no significant changes in blood composition (Khan et al., 2013; Al-Saad et al., 2014).

On the other hand, when feeding birds with Bacilli there is an increase in the number of red blood cells, hemoglobin, etc. (Rahman et al., 2014; Cetin et al., 2005; Abd El-Hack et al., 2016). This is due to the stimulating effect of probiotic supplements of Bacillus genus bacteria on the organs of hemopoiesis.

The content of glucose in the blood serum significantly increased in comparison to the control.

Carbohydrates are the most quickly involved compounds in the production of energy in the animal body. The main carbohydrate of blood plasma is glucose, the content of which for each animal species keeps at a relatively constant level, although functioning cells of the body continuously absorb glucose from the blood to cover their energy costs. Elevated glucose levels may be associated with bacterial enzymes. As was shown above, Bacillus produce proteolytic enzymes that improve the digestibility of feed (Amoa-Awua et al., 2006).

But what is the reason for such changes?

First of all, this is due to the production of metabolites exhibiting antioxidant and DNA-protective properties, by the Bacillus strains as shown in our work (Prazdnova et al., 2015).

By using a system of bacterial Lux-biosensors, it was found that metabolites of $B$. amyloliquefaciens B-1895 showed slightly lower antioxidant and DNA-protective activity than those of B. subtilis KATMIRA1933. In this case, two types of activity are provided by different substances or groups of substances. It was also noted that such properties are characteristic even of a dry preparation prepared by solid-phase fermentation (Prazdnova et al., 2015). 
Physiological studies revealed that 70 days after starting the administration of preparations containing Bacillus subtilis KATMIRA1933 and Bacillus amyloliquefaciens B-1895, only Bacillus amyloliquefaciens $B-1895$ cells were found in the birds' excrements. The complete "assimilation" of the KATMIRA1933 spores by chickens is a fundamental difference in the effect of this strain from $B-1895$.

In addition, when two strains are used, the physiological effect of acceleration of mass gain is much weaker when using the mixed supplement, than when using strains separately. We assumed that antagonism between the two strains can cause this effect. To test it, an experiment was performed to determine the antagonism between these bacteria in vitro. However, according to the results of the experiment antagonism between the strains was not detected, moreover, the colonies of bacteria on the dish merged.

In the article by Engelberg-Kulka et al. (2006) the "suicide" of bacteria under the influence of factors produced by a part of the population in the time of resource shortage is described. However, if there was such a kind of interaction between the strains studied, we should have seen it in the joint cultivation.

Another cell death mechanism described in the article is the production of the "toxin-labile antitoxin" system by the cell, which is triggered by various stress factors such as lack of sufficient nutrients, heat shock, oxidative stress, DNA damage, antibiotics, phages. However, the induction of this system in the cell by factors produced by surrounding cells is not described.

Significant differences between $B$. subtilis KATMIRA1933 and B. amyloliquefaciens B-1895 is the ability of the KATMIRA1933 strain to produce subtilosin A (Algburi et al., 2017). This substance is a cyclic anionic antibiotic belonging to bacteriocins (genetically encoded antimicrobial proteins of bacterial origin) that interacts with the surface receptor and electrostatically binds to the membrane of bacterial cells sensitive to its action.

The most important property of subtilosin A is its ability to suppress the biofilm formation in various bacteria (Algburi et al., 2017). The formation of biofilms is regulated by signal molecules related to the so-called Quorum Sensing mechanism (QS). It was shown that subtilosin A reduces biofilm formation in Gram-positive (Listeria monocytogenes, strain ScottA), Gram-negative (Escherichia coli, strain/serotype O157: H7) and Gramvariable bacteria (Gardnerella vaginalis, strain ATCC 14018) (Algburi et al., 2017).

Such effects can allow a significant transition of gut microbes to planktonic form and therefore activation of nonspecific immunity. We can assume that the lack of cells (KATMIRA1933 strain) in excreta is associated with bird gut antibacterial system activation by massive symbiotic biofilm destruction by subtilosin. Checking whether this mechanism works in vivo is the task of further experiments.

\section{Conclusion}

All data, obtained as a result of experiments lead us to the following conclusion: usage of probiotic drugs based on Bacillus subtilis KATMIRA1933 and Bacillus amyloliquefaciens B-1895 strains have a positive influence on the growth and health status of rearing birds. Living weight, the number of erythrocytes, hemoglobin and total protein concentration in blood increased. There were no noted pathological changes of microbiota. Because of cheap drug production methods based on fermentation of soybeans, using such drugs can be highly effective in modern animal husbandry.

\section{Funding Information}

The work was done with the support of the project RSF № 16-16-04032.

\section{Author's Contributions}

Chickindas, M.L., I.F. Gorlov: Conceived and designed the experiments, analyzed the data.

Usatov, A.V., Z.B. Komarova: Performed the experiments, analyzed the data.

Klimenko, A.I.: Analyzed the data.

Mosolova, N.I., O.E. Krotova and A.N. Struk: Performed the experiments.

Mazanko, M.S. and M.A. Kolosova: Analyzed the data, wrote the manuscript.

\section{Ethics}

Animal testing was conducted in accordance with the principles of the European Convention for the Protection of Vertebrate Animals, used for experiments or other scientific purposes.

\section{References}

Abd El-Hack, M.E., S.A. Mahgoub, M. Alagawany and E.A. Ashour, 2016. Doping with or without Bacillus subtilis probiotic. J. Animal Physiology Animal Nutrition.

Aguilar, C.N., G. Gutierrez-Sánchez, P.A. radoBarragán, R. Rodríguez-Herrera and J.L. MartínezHernandez et al., 2008. Perspectives of solid state fermentation for production of food enzymes. Am. J. Biochem. Biotechnol., 4: 354-366.

Algburi, A., S. Zehm, V. Netrebov, A.B. Bren and V. Chistyakov et al., 2017. Subtilosin preventing biofilm formation by inhibiting bacterial quorum sensing. Probiotics Antimicrobial Proteins, 9: 81-90. 
Al-Gburi, A., A. Volski, C. Cugini, E.M. Walsh and V.A. Chistyakov et al., 2016. Safety properties and probiotic potential of Bacillus subtilis KATMIRA1933 and Bacillus amyloliquefaciens B1895. Advances Microbiol., 6: 432-452.

Allen, H.K., U.Y. Levine, T. Looft, M. Bandrick and T.A. Casey, 2013. Treatment, promotion, commotion: Antibiotic alternatives in food-producing animals. Trends Microbiology, 21: 114-119. DOI: $10.1016 /$ j.tim.2012.11.001

Al-Saad, S., M. Abbod and A. Abo Yones, 2014. Effects of some growth promoters on blood hematology and serum composition of broiler hens. Int. J. Agric. Res., 9: 265-270.

Amoa-Awua, W.K., N.N. Terlabie and E. SakyiDawson, 2006. Screening of 42 Bacillus isolates for ability to ferment soybeans into dawadawa. Int. J. Food Microbiol., 343-347.

Angelakis, E., 2016. Weight gain by gut microbiota manipulation in productive animals. Microbial Pathogenesis, 106: 162-170. DOI: $10.1016 /$ j.micpath.2016.11.002

Blajman, J.E., M.V. Zbrun, D.M. Astesana and A.P. Berisvil et al., 2015. Probiotics in broilers' rearing: A strategy for intensive production models. Revista Argentina de Microbiologia, 47: 360-367. DOI: 10.1016/j.ram.2015.08.002

Cetin, N., B.K. Guclu and E. Cetin, 2005. The effects of probiotic and mannanoligosaccharide on some haematological and immunological parameters in Turkeys. J. Vet. Medicine Series A - Physiology Pathology Clinical Medic., 52: 263-267. DOI: $10.1111 /$ j.1439-0442.2005.00736.x

Chistyakov, V., V. Melnikov, M.L. Chikindas, M. Khutsishvili and A. Chagelishvili et al., 2015. Poultrybeneficial solid-state Bacillus amyloliquefaciens B1895 fermented soybean formulation. Biosci Microbiota Food Health, 34: 25-28.

DOI: $10.12938 / \mathrm{bmfh} .2014-012$

Coles, E.H., 1986. Kidney function. Veterinary Clinical Pathology, Fourth Edition, WB Saunders Company, Philadelphia. pp: 468.

Diarra, M.S. and F. Malouin, 2014. Antibiotics in Canadian poultry productions and anticipated alternatives. Frontiers Microbiology Editorial Office, 17: 282. DOI: 10.3389/fmicb.2015.01138

Engelberg-Kulka, H., S. Amitai, I. Kolodkin-Gal and R. Hazan, 2006. Bacterial programmed cell death and multicellular behavior in bacteria. PLoS Genetics, 2: e135. DOI: 10.1371/journal.pgen.0020135

Ghadban, G.S., 2002. Probiotics in broiler production-a review. Archiv Fur Geflugelkunde, 66: 49-58.

Hisex Brown Guide CS. 2010.: 32
Jeong, J.S. and I.H. Kim, 2014. Effect of Bacillus subtilis C-3102 spores as a probiotic feed supplement on growth performance, noxious gas emission and intestinal microbiota in broilers. Poultry Sci., 93: 3097-3103. DOI: $10.3382 /$ ps.2014-04086

Jeong, J.S. and I.H. Kim, 2014. Effect of Bacillus subtilis C-3102 spores as a probiotic feed supplement on growth performance, noxious gas emission and intestinal microbiota in broilers. Poultry Sci., 93: 3097-3103. DOI: $10.3382 /$ ps.2014-04086

Karlyshev, A.V., V.G. Melnikov and M.L. Chikindas, 2014. Draft genome sequence of Bacillus subtilis strain KATMIRA1933. Genome Announcements, 2: e00619-14. DOI: 10.1128/genomeA.00619-14

Khan, S.H., A. Rehman, R. Sardar and T. Khawaja, 2013. The effect of probiotic supplementation on the growth performance, blood biochemistry and immune response of reciprocal F1 crossbred (Rhode Island Red $\times$ Fayoumi) cockerels. J. Applied Anim. Res., 41: 417-426.

Li, Y.B., Q.Q. Xu, C.J. Yang, X. Yang and L. Lv et al., 2014. Effects of probiotics on the growth performance and intestinal micro flora of broiler hens. Pakistan J. Pharmaceutical Sci., 27: 713-717.

Liu, L., Y. Liu, H.D. Shin, R.R. Chen and N.S. Wang, 2013. Developing Bacillus sp. As a cell for production of microbial enzymes and industrially important biochemicals in the context of systems and synthetic biology. Applied Microbiol. Biotechnol., 97: 6113-6127.

DOI: $10.1007 / \mathrm{s} 00253-013-4960-4$

Liu, X.L., H. Yan, L. Lv, Q.Q. Xu and C.H. Yin et al., 2012. Growth performance and meat quality of broiler hens supplemented with Bacillus licheniformis in drinking water. Asian-Australasian J. Anim. Sci., 25: 682-689.

DOI: 10.5713 ajas.2011.11334

Mookiah, S., C.C. Sieo, K. Ramasamy, N. Abdullah and Y.W. Ho, 2014. Effects of dietary prebiotics, probiotics and synbiotics on performance, caecal bacterial populations and caecal fermentation concentrations of broiler hens. J. Sci. Food Agric., 94: 341-348.

Mountzouris, K.C., P. Tsirtsikos, E. Kalamara, S. Nitsch and G.K.F. Schatzmayr, 2007. Evaluation of the efficacy of a probiotic containing Lactobacillus, Bifidobacterium, Enterococcus and Pediococcus strains in promoting broiler performance and modulating cecal microbiota composition and metabolic activities. Poultry Sci., 86: 309-317. 
NRC, 1994. Nutrient Requirements of Poultry. 9th Edn., Natl. Acad. Press, Washington, DC, USA.

Paul, A., 2009. Chicken to fare better than other meats. Poultry USA, 10: 16.

Prazdnova, E.V., V.A. Chistyakov, M.N. Churilov, M.S. Mazanko and A.B. Bren et al., 2015. DNAprotection and antioxidant properties of fermentates from Bacillus amyloliquefaciens B-1895 and Bacillus subtilis KATMIRA1933. Letters Applied Microbiol., 61: 549-554. DOI: 10.1111/lam.12491

Rahman, M.S., A. Mustari, M. Salauddin and M.M. Rahman, 2014. Effects of probiotics and enzymes on growth performance and haematobiochemical parameters in broilers. J. Bangladesh Agric. University, 11: 111-118.

Stanton, T.B., 2013. A call for antibiotic alternatives research. Trends Microbiol., 21: 111-113. DOI: $10.1016 /$ j.tim.2015.10.002
Sutyak, K.E., R.E. Wirawan, A.A. Aroutcheva and M.L. Chikindas, 2008. Isolation of the Bacillus subtilis antimicrobial peptide subtilosin from the dairy product derived Bacillus amyloliquefaciens. J. Applied Microbiol., 104: 1067-1074.

DOI: $10.1111 / \mathrm{j} .1365-2672.2007 .03626 . \mathrm{x}$

Terry, E., 2008. Poultry now a third of all meats. Poultry International, 47: 30-32.

Timmerman, H.M., A. Veldman, E. van den Elsen, F.M. Rombouts and A.C. Beynen, 2006. Mortality and growth performance of broilers given drinking water supplemented with chicken-specific probiotics. Poultry Sci., 85: 1383-1388. DOI: $10.1093 / \mathrm{ps} / 85.8 .1383$

Ushakova, N.A., V.M. Abramov, V.S. Khlebnikov, A.M. Semenov and B.B. Kuznetsov et al., 2012. Properties of the probiotic strain Lactobacillus plantarum 8-RA-3 grown in a biofilm by solid substrate cultivation method. Probiotics Antimicrobial Proteins, 4: 180-186. 